\title{
THE EFFECTIVENESS OF SPATIAL ANALOGIES ON UNDERSTANDING OF NUMBERS IN EARLY CHILDHOOD
}

\author{
Yayang Honora Prabu Sinta ${ }^{1)}$, Siti Kamsiyati ${ }^{2}$ ), Muhammad Munif ${ }^{3)}$ \\ Pendidikan Guru Pendidikan Anak Usia Dini, Universitas Sebelas Maret ${ }^{1)}$ \\ Pendidikan Guru Sekolah Dasar, Universitas Sebelas Maret ${ }^{2)}$ \\ Pendidikan Guru Pendidikan Anak Usia Dini, Universitas Sebelas Maret ${ }^{3)}$ \\ yayangsinta01@gmail.com
}

\begin{abstract}
This study aimed to examine the effectiveness of spatial analogies on understanding of numbers in early childhood in TK Islam Salamah and TK Sri Juwita Hanum Surakarta. This study was a quasiexperimental. The design of the study used a non-equivalent design with a sample of 34 children in the experimental group and 35 children in the control group. The technique of collecting data was through performance tests to measure children's understanding of numbers. The normality test and homogeneity test used kolmogrov smirnov and lavene test of equality of variance. The data analysis used parametric statistics with a significance level $p>0.05$. The results showed that there was an increase in the mean value in the experimental group and there were significant differences from the control group and the experimental group with a significance value of 0,000 . Children can to use the number symbol to count, mention the number symbol from 1 to 10 , match numbers with the number symbols, know the concept of less and more numbers also there was an increase in another indicator. It can be concluded that spatial analogies had an effectiveness on the understanding of numbers of children in group B, TK Islam Salamah Surakarta.
\end{abstract}

Keywords: spatial analogies, understanding of numbers, early childhood

\section{EFEKTIVITAS SPATIAL ANALOGIES TERHADAP PEMAHAMAN ANGKA PADA ANAK USIA DINI}

\begin{abstract}
Abstrak: Penelitian ini bertujuan untuk menguji efektifitas spatial analogies terhadap pemahaman angka pada anak usia dini di TK Islam Salamah dan TK Sri Juwita Hanum Surakarta. Penelitian ini menggunakan jenis penelitian quasi eksperimen. Desain penelitian yang digunakan non-equivalent design dengan sampel kelompok eksperimen sejumlah 34 anak dan kelompok kontrol sejumlah 35 anak. Teknik pengumpulan data melalui tes untuk mengukur pemahaman angka anak. Uji normalitas dan uji homogenitas menggunakan kolmogrov smirnov dan lavene test of equality of variance. Analisis data penelitian menggunakan taraf signifikansi $p>0,05$. Hasil penelitian menunjukkan bahwa terdapat peningkatan nilai rata-rata pada kelompok eksperimen dan terdapat perbedaan yang signifikan dari kelompok kontrol dan kelompok eksperimen dengan nilai signifikansi 0,000. Hal ini dibuktikkan melalui 29 dari 34 anak memiliki pemahaman angka sangat baik yang mampu dalam menggunakan lambang bilangan untuk menghitung, menyebutkan lambang bilangan 1 sampai 10, mencocokkan bilangan dengan lambang bilangan, mengetahui konsep bilangan banyak sedikit serta terdapat peningkatan pada indikator lainnya. Berdasarkan uraian di atas dapat disimpulkan bahwa spatial analogies memberikan efektifitas terhadap pemahaman angka pada anak kelompok B TK Islam Salamah Surakarta.
\end{abstract}

Kata Kunci: spatial analogies, pemahaman angka, anak usia dini

\section{PENDAHULUAN}

Salah satu aspek perkembangan yang penting bagi anak usia dini yaitu perkembangan kognitif. Pengembangan pengetahuan angka di awal merupakan proses kognitif yang kompleks dimana anak memperoleh kompetensi numeric. Keterampilan 
matematika awal pada anak penting untuk pencapaian akademik selanjutnya (Navarrete \& Daniel, 2018) [1].

\section{Salah satu keterampilan}

matematika awal anak adalah pemahaman angka. Pemahaman angka untuk anak yaitu kemampuan seorang anak untuk memahami lebih dari mengetahui dan menghafal tetapi anak juga dapat mengetahui makna sebuah angka dari bahan yang dipelajari. Pada anak usia dini yang diperoleh pertama kali dalam pemahaman angka yakni pengenalan angka dengan diwakilkan simbol dari nomor yang berurutan antara lain $0,1,2,3,4,5,6,7,8,9,10$. Peraturan Menteri Pendidikan Dan Kebudayaan Republik Indonesia Nomor 137 Tahun (2014) [2] menyatakan anak usia 5 sampai 6 tahun dalam aspek perkembangan kognitif mampu: 1) menyebutkan lambang bilangan, 2) menggunakan lambang bilangan untuk menghitung, 3) mencocokan bilangan dengan lambang bilangan. Peraturan Menteri Pendidikan dan Kebudayaan Republik Indonesia Nomor 146 Tahun (2014) [3] mengungkapkan anak usia 4 sampai 6 tahun mampu dalam mengetahui konsep bilangan banyak sedikit (besaran angka), membilang benda dari 1-10, mengenal konsep bilangan, mengenal lambang bilangan.

Studi (Siegler \& Ramani, 2008; Whyte \& Bull, 2008) [4] menunjukkan anak-anak prasekolah dapat menghitung dengan sempurna dari 1 sampai 10 , tetapi belum memahami urutan peringkat dari besaran angka. Pemahaman yang kurang tentang besaran angka pada anak prasekolah yakni ketika membandingkan besarnya angka dari 1 sampai 10.

Studi lain dari peneliti berdasarkan hasil observasi, wawancara dan uji coba yang dilakukan pada hari Jum'at, 15 Desember 2018 bahwa dalam kenyataan yang terjadi di sekolah, sebanyak $65 \%$ dari 35 anak yaitu sejumlah 23 anak masih dalam tahap mulai berkembang memahami angka yakni, anak dapat memahami besaran angka lebih besar maupun lebih kecil, menghubungkan bilangan1 sampai 10 dengan lambang bilangan, menghubungkan lambang bilangan 1 sampai 10 dengan jumlah benda, menghitung penambahan dengan benda 1 sampai 10 tetapi masih dengan bantuan guru. Hal tersebut dikarenakan kuranganya variasi dalam pembelajaran mengenai pemahaman angka.

Adapun metode pembelajaran angka yang digunakan di TK menggunakan lembar kerja anak dalam meningkatkan pengetahuan matematika anak khususnya pemahaman angka. Kondisi seperti diatas menunjukkan bahwa antara kenyataan di lapangan kurang sinkron dengan capaian perkembangan anak dalam aspek kognitif khususnya pada pemahaman angka.

Upaya peneliti dalam mengatasi permasalahan diatas yaitu menggunakan spatial analogies dengan melalui kegiatan permainanan papan linear angka. Teknik analogi atau analogies adalah suatu teknik mengajar yang berusaha menciptakan suatu cerita untuk mengilustrasikan sebuah konsep (Kamsiyati, 2012) [5]. Mix dan Cheng (Erica, 2018) [6] keterampilan spasial adalah keterampilan kognitif inti seperti visualisasi spasial (kemampuan untuk membayangkan dan mengubah informasi spasial secara mental), membentuk persepsi (kemampuan untuk menyalin dan membedakan bentuk dari bentuk lain, termasuk simbol), dan visual-spatial.

Spatial analogies merupakan desain pembelajaran yang berbasis analogi yakni menciptakan suatu cerita untuk mengilustrasikan sebuah konsep dengan menggunakan keterampilan spasial (struktur ruang) untuk dapat mempresentasikan angka (Navarrete \& Daniel, 2018) [1]. 
Spatial analogies adalah salah satu mekanisme yang memungkinkan anak untuk mengasosiasikan angka dan representasi besarnya. Tujuan spatial analogies meningkatkan pengetahuan anak tentang ruang (pengetahuan spasial), yang diwakili dalam kotak spasial pada permainan papan linear angka dengan struktur ruang. Informasi angka dikodekan secara spasial menjadi berorientasi kiri ke kanan (Navarrete \& Daniel, 2018) [1]. Spatial analogies mempunyai manfaat sebagai berikut: pertama, mengajarkan matematika anak dengan pendekatan yang berbeda yang bermanfaat untuk mengajar anak tentang angka. Kedua, mendorong pengetahuan angka. Ketiga, meningkatkan belajar anak mengenai pengetahuan angka. Keempat, sarana pembelajaran pengetahuan matematika awal anak, dengan pengalaman yang menyenangkan (Navarrete \& Daniel, 2018) [1].

Pada penelitian ini, spatial analogies dilakukan melalui kegiatan permainanan papan linear angka. Permainan papan linear angka yaitu permainan papan yang diatur secara linear, ruang yang diberi nomor berurutan, dan berukuran sama yang dapat memberikan isyarat untuk urutan angka dan besaran angka (Siegler dalam Navarrete \& Daniel, 2018) [1].

Permainan papan linear angka mengembangkan aspek kognitif pada pemahaman angka yaitu mengurutkan nomor, mengidentifikasi angka, mengetahui konsep besaran angka, menghitung (Siegler \& Ramani, 2008) [4]. Permainan papan linier angkaangka 1 sampai 10 memberikan pengalaman visuospasial, kinestetik dan pendengaran temporal (Siegler \& Ramani, 2009) [7].

Navarrete dan Daniel, (2018) [1] mengungkapkan permainan papan linear angka memiliki kelebihan dan kekurangan, adapun kelebihannya antara lain permainan papan linear angka lebih unggul dalam pengetahuan angka, metode pengajaran pengetahuan matematika dengan cara menyenangkan, dapat dilatih baik di rumah maupun di lingkungan sekolah, menyediakan pengalaman yang kaya angka. Kekurangan permainan papan linear angka yakni sebagai berikut papan linear angka yang terdiri dari 10 papan berbentuk persegi yang disusun linear memungkinkan anak bosan karena tidak ada variasi dari segi fisik permainan yang hanya lurus kedepan, permainan papan linear angka membutuhkan tempat luas, tidak bisa dilakukan didalam kelas karena membutuhkan tempat yang luas

Sedangkan papan linear symbol hampir sama dengan permainan papan linear angka, yang membedakan adalah setiap nomor yang dicetak pada papan permainan digantikan oleh ilustrasi non angka yang berupa simbol atau gambar yang masih berkaitan dengan cerita atau dongeng yang akan dibawakan pada permainan ini. Jumlah gambar yang digunakan dalam permainan papan linear non angka adalah 10 gambar. Perkembangan yang dikembangkan dalam permainan papan linear angka yaitu bahasa, kognitif, fisik motorik, dan sosioafektif.

Berdasarkan uraian di atas, peneliti berharap dengan adanya penerapan spatial analogies pada kegiatan permainan papan linear angka dapat mengembangkan pemahaman angka pada anak.

\section{METODE PENELITIAN}

Penelitian yang dilaksanakan termasuk dalam penelitian quasi eksperimental design dengan tipe non equivalent control group design. Penelitian ini dilakukan di TK Islam Salamah Mojosongo dan TK Sri Juwita Hanum Mojosongo. Penelitian dilaksanakan pada anakberusia 5-6 tahun. Penelitian dilakukan dengan 
jangka waktu tujuh bulan dimulai dari bulan Desember 2018 sampai dengan Juni 2019.

Populasi dalam penelitian ini yaitu satu gugus yang terdiri dari lima TK yang selanjutnya diambil dua TK secara acak, terpilih dua TK yakni TK Islam Salamah dan TK Sri Juwita Hanum Surakarta sejumlah 69 anak berusia 5-6 tahun. Selanjutnya, semua responden sejumlah 69 anak terdiri dari sampel 34 anak sebagai kelompok eksperimen dan 35 anak menjadi sampel kelompok kontrol.

Teknik pengambilan sampel yang digunakan dalam penelitian ini yaitu teknik random sampling. Metode pengumpulan data dilakukan melalui tes untuk mengetahui kemampuan pemahaman angka pada anak, tes yang dilakukan berupa pretest dan postest. Penilaian terhadap hasil tes, menggunakan rating scale yang memiliki nilai skala 1-4.

Uji validitas yang digunakan yaitu validitas isi, dalam menguji validitas isi, digunakan pendapat dari ahli (judgement experts). Pengujian daya beda item dalam penelitian ini melalui teknik corrected item-total correlation dengan bantuan SPSS 15 for windows. Uji reliabilitas dalam penelitian ini menggunakan alpha cronbach's dengan bantuan SPSS 15 for windows. Teknik analisis data, uji prasyarat analisis melalui uji normalitas dengan menggunakan kolmogrov smirnov, sedangkan uji homogenitas dilakukan dengan menggunakan laevene test of equality of variance. Uji hipotesis menggunakan independent sample t-tes dengan bantuan SPSS 15 for windows.

\section{HASIL DAN PEMBAHASAN}

Deskripsi data pada penelitian diperoleh hasil dari pretest dan posttest yang telah dilakukan. Penelitian ini dilaksanakan di TK Islam Salamah sebagai kelompok eksperimen dengan subjek penelitian sebanyak 35 anak dan
TK Sri Juwita Hanum dengan subjek penelitian sebanyak 34 anak sebagai kelompok kontrol.

Penelitian ini dilaksanakan dengan pemberian pretest, perlakuan (treatment), postest dengan 8 butir item yang telah diuji cobakan sebelumnya. Pretest dilakukan terlebih dahulu untuk mengetahui keadaan awal kemampuan pemahaman angka anak sebelum dilaksanakan treatment atau perlakuan berupa spatial analogies dengan permainan papan linear angka.

Pemberian perlakuan dilakukan pada kelompok eksperimen menggunakan spatial analogies melalui permainan papan linear angka sedangkan kelompok kontrolmelalui permainan papan linear simbol, atau non angka atau gambar, selanjutnya dilakukan postest guna untuk mengukur kemampuan pemahaman angka anak pada kelompok kontrol dan kelompok eksperimen dengan indikator penelitian yang sama.

Tabel 1. Deskripsi Data

\begin{tabular}{llccc}
\hline & Kelompok & Min & Mak & Mean \\
\hline Pretest & Eksperimen & 17 & 24 & 21,29 \\
& Kontrol & 16 & 24 & 20,53 \\
Postest & Eksperimen & 22 & 32 & 28,46 \\
& Kontrol & 17 & 24 & 21,32 \\
\hline
\end{tabular}

Data pretest dan postest pada kelompok kontrol dan kelompok eksperimen memiliki nilai terendah (min), nilai tertinggi. Hasil nilai ratarata (mean) pada kelompok eksperimen menunjukkan peningkatan nilai yang lebih besar daripada hasil nilai rata-rata pada kelompok kontrol, meskipun kelompok kontrol juga mengalami peningkatan. Data hasil nilai diatas menunjukkan bahwa pemahaman angka anak pada kelompok 
eksperimen diperoleh hasil nilai rata-rata (mean) yang lebih tinggi pada pretest dan postest dibandingkan dengan hasil nilai rata-rata (mean) kelompok kontrol. Tabel2.Uji Normalitas

$P \quad p$ hasil analisis

\begin{tabular}{lll}
\hline Pretest & $p>0,05$ & 0,077 \\
Postest & & 0,143
\end{tabular}

Hasil uji normalitas menunjukkan bahwa tingkat signifikansi pada pretest kelompok kontrol yaitu sebesar 0,72 dan kelompok eksperimen sebesar 0,77. Tingkat signifikansi pada postest kelompok kontrol adalah 0,85 sedangkan kelompok eksperimen 0,143. Hasil data di atas dapat disimpulkan yaitu kedua data dari hasil uji normalitas diperoleh nilai signifikansi lebih dari 0,05, sehingga data tersebut dapat dinyatakan berdistribusi normal.

Tabel 3. Uji Homogenitas

$$
P \quad p \text { Hasil Analisis }
$$

\begin{tabular}{ll}
\hline Pretest $\quad p>0,05$ & 0,241 \\
& \\
Postest & 0,208 \\
\hline
\end{tabular}

Uji Homogenitas yang digunakan yaitu lavene test equality of variance. Dasar keputusan yakni apabila signifikansi $p>0,05$ maka data dinyatakan homogen (sama) normal. Berdasarkan hasil analisis menunjukkan bahwa, nilai signifikansi uji homogenitas pretest sebesar 0,241 ; nilai signifikansi uji homogenitas postest pada sebesar 0,208. Berdasarkan pengujian diatas, dapat disimpulkan bahwa data hasil uji homogenitas kedua kelompok tersebut dinyatakan normal dengan tingkat signifikansi $\mathrm{p}>0,05$.
Uji hipotesis pada penelitian ini menggunakan teknik analisis yaitu independent sample t-test dengan bantuan SPSS 15 for windows, dasar pengambilan keputusan adalah terdapat perbedaan yang signifikan jika $p>0,05$ dan apabila nilai signifikansi $\mathrm{p}<0,05$ maka tidak terdapat perbedaan.

Tabel 4. Uji independent sample t-test

\begin{tabular}{llllc}
\hline Test & $\begin{array}{c}\text { Kelom } \\
\text { pok }\end{array}$ & $\mathrm{N}$ & Mean & $\mathrm{P}$ \\
\hline $\begin{array}{l}\text { Pret } \\
\text { est }\end{array}$ & $\begin{array}{l}\text { Eksperi } \\
\text { men }\end{array}$ & 35 & 20,53 & 0,123 \\
& Kontrol & 34 & 21,29 & \\
Post & Eksperi & 35 & 21,32 & 0,000 \\
est & men & & & \\
& Kontrol & 34 & 28,46 & \\
\hline
\end{tabular}

Berdasarkan uji independent sample t-test di atas menunjukkan pada kelompok eksperimen dan kontrol saat pretest diperoleh nilai signifikansi angka lebih besar 0,05 yakni 0,122 berarti tidak terdapat perbedaan yang signifikan dari kelompok kontrol dan eksperimen sebelum diberikan treatment. Selanjutnya pada saat postest kelompok eksperimen dan kelompok kontrol menunjukkan nilai signifikansi yang lebih kecil dari 0,05 yaitu sebesar 0.000 artinya terdapat perbedaan yang signifikan dari kelompok kontrol dan kelompok eksperimen setelah diberikan tiga kali treatment spatial analogies.

Berdasarkan penelitian yang telah dilakukan, dapat diketahui terdapat pengaruh spatial analogies terhadap pemahaman angka pada anak usia 5-6 tahun. Hasil pretest pada kelompok kontrol memperoleh nilai mean 20,53, sedangkan hasil postest pada kelompok kontrol adalah sebesar 21,32. Kelompok kontrol memperoleh 
nilai pretest 20,53 dan nilai postest 21,32 dengan selisih yaitu 0,79 . Hasil pretest pada kelompok eksperimen memperoleh nilai mean 21,29. Hasil postest pada kelompok eksperimen memiliki nilai mean yaitu sebesar 28,46. Kelompok eksperimen memiliki nilai pretest sebesar 21,29 dan nilai postest sebesar 28,46, sehingga selisih angka pada nilai pretest dan postest yaitu 7,17.

Nilai mean pretest pada kelompok eksperimen dan kelompok kontrol memperoleh hasil yang hampir sama, sedangkan nilai rata-rata postest pada kelompok eksperimen meningkat dibandingkan dengan kelompok kontrol. Hal tersebut menunjukkan setelah pemberian treatment, pemahaman angka pada kelompok eksperimen, mengalami peningkatan dari kondisi awal sebelum mendapatkan treatment yang berupa spatial analogies dengan permainan papan linear angka.

Hasil uji hipotesis menunjukkan perbedaan signifikan yakni 0,000 pada kelompok kontrol dan eksperimen setelah diberikan treatment. Hasil dari analisis data yang telah dilakukan yaitu terdapat adanya perbedaan signifikan pada nilai rata-rata (mean) dikelompok eksperimen maupun kelompok kontrol, walaupun kedua kelompok tersebut menunjukkan hasil dari kedua kelompok sama meningkat. Kelompok eksperimen memperoleh nilai mean lebih besar daripada kelompok kontrol, sehingga spatial analogies dengan permainan papan linear angka lebih efektif terdapat pemahaman angka pada anak usia 5-6 tahun. Berikut merupakan beberapa hal yangmendasari bahwa spatial analogies dengan permainan papan linear angka berpengaruh terhadap pemahaman angka pada anak usia 5-6 tahun.

Pertama, spatial analogies pada pembelajaran angka anak yaitu mempertimbangkan desain pengajaran matematika anak dengan pendekatan yang berbeda dan pengalaman yang berbeda bermanfaat untuk mengajarkan anak tentang pembelajaran angka yaitu dengan permainan papan linear angka. Permainan papan linear angka lebih unggul untuk mempromosikan kinerja anak-anak dalam berbagai tugas numerik salah satunya pemahaman angka. Anak-anak pada kelompok eksperimen lebih antusias dalam belajar mengenai pembelajaran angka dengan bermain permainanpapan linear angka, selain itu anak lebih suka penerapan permainan yang dilakukan diluar kelas atau di outdoor. Hal tersebut dapat membantu anak untuk dapat mudah dalammemahami angka dalam pembelajaran angka menjadi lebih baik dari sebelumnya.

Kedua, desain spatial analogies, pengalaman bermain dapat dijadikan sarana pembelajaran pengetahuan matematika awal anak, yang dapat dijadikan alternatif dalam mempromosikan pengetahuan numeric pada anak dengan pengalaman yang menyenangkan (Navarrete \& Daniel, 2018) [1]. Permainan papan linier angka dalam kisaran numerik 1 sampai 10 memberikan pengalaman visuospasial antara lain dengan tata ruang dan visual pemetaan permainan papan linear angka, sedangkan kinestetik yakni dari gerakan-gerakan anak dalam memainkan permainan tersebut, pendengaran temporal yaitu dari aba-aba yang diberikan peneliti dengan cara menyenangkan yakni melalui bermain, dikarenakan bermain merupakan aspek dasar pendidikan anak usia dini (Navarrete \& Daniel, 2018) [1].

Ketiga, spatial analogies dengan permainan papan linear angka dapat mengembangkan aspek kognitif terhadap pemahaman angka anak, antara lain mengurutkan nomor, mengidentifikasi angka, mengetahui konsep banyak sedikit (besaran angka), menghitung. Selain 
mengembangkan aspek perkembangan kognitif, spatial analogies dengan permainan papan linear angka juga dapat mengembangkan pada aspek bahasa, motorik dan sosio afektif. Aspek bahasa yaitu anak dapat menunjukkan kemampuan berbahasa ekspresif pada saat bermain, aspek motorik yaitu anak dapat menggunakan anggota tubuhnya untuk mengembangkan motorik halus dan motorik kasarnya antara lain melompat, berlari, berjalan, menempel, sedangkan aspek sosio afektif yaitu melatih kerja sama anak, mengekspresikan emosi yangsesuai dengan kondisi anak saat bermain.

Penelitian ini menerapkan tiga kali treatment pada kelompok eksperimen yaitu melalui spatial analogies dengan permainan papan linear angka, kelompok kontrol dengan permainan papan linear non angka atau simbol. Pemberian setiap treatment melalui tiga tahap antara lain pertama permainan papan linear angka pada kelompok eksperimen dengan membacakan dongeng kelinci dan kura-kura dan pemberian token berupa gambar, guru memberi contoh praktek dalam bermain. Permainan papan linear angka ini anak dibagi menjadi dua kelompok antara lain kelompok kancil dan kelompok kurakura. Tahap kedua adalah mengulang kembali membacakan dongeng, anak mulai praktek tanpa bantuan guru. Selanjutnya, tahap ketiga merancang permainan menjadi sebuah game yang terdiri dari dua kelompok yakni kelompok 1 yaitu kelompok kancil dan kelompok 2 yaitu kelempok kelinci.

Berdasarkan hasil dari observasi yang dilakukan pada saat pretest, kelompok eksperimen menunjukkan bahwa sebagian besar anak masih belum dapat membandingkan konsep banyak sedikit, dan masih belum sepenuhnya terampil dan tepat dalam mengurutkan angka, mencocokkan angka dengan lambang bilangan, menghubungkan bilangan dengan benda, serta menghitung penambahan dengan benda. Setelah diberikan treatment, pada saat postest anak kelompok eksperimen menunjukkan adanya perubahan yang lebih baik dari sebelum diberikan treatment, antara lain yaitu mampu membandingkan konsep banyak sedikit (besaran angka), mengurutkan angka 1 sampai 10, mencocokkan angka dengan lambang bilangan, dan menghubungkan bilangan dengan benda, serta dapat menghitung penambahan dengan benda, hasil penelitian terdapat sebagian besar anak sudah berkembang sesuai harapan, tepat dan juga terampil.

Sedangkan pada saat pretest dan postest hasil observasi menunjukkan bahwa hanya terdapat sedikit anak yang menunjukkan perubahan dalam pemahaman angka setelah diberikan treatment, hal tersebut berbeda dengan kelompok eksperimen, sehingga dapat disimpulkan bahwa spatial analogies dengan permainan papan linear angka berpengaruh pada pemahaman angka pada anak usia 5-6 tahun pada kelompok eksperimen.

Salah satu faktor yang menjadi pengaruh dalam pemahaman angka anak selama penelitian berlangsung yakni kehadiran anak selama proses pemberian treatment. Anak yang mengikuti treatment selama tiga kali akan berbeda dengan anak yang hanya mengikuti satu atau dua treatment. Anak yang mengikuti lebih sedikit treatment, kemampuan dalam pemahaman angkanya sudah berkembang sesuai harapan tetapi belum sepenuhnya terampil, dan belum dapat dikatakan berkembang sangat baik.Beberapa hal yang ditemukan peneliti selama penelitian berlangsung, adalah anak lebih antusias dalam melaksanakan pembelajaran yang dilakukan diluar kelas, selain itu anak lebih tertarik pada permainan yang melibatkan 
suatu kelompok untuk bekerja samadeangan tim dalam sebuah permainan. Berdasarkan hal tersebut dapat disimpulkan dalam penerapan spatial analogies dengan permainan papan linear angka ini memberikan manfaat selain untuk aspek kognitif, tetapi juga untuk aspek bahasa, motorik dan aspek afektif anak.

\section{SIMPULAN}

Penelitian ini menguji efektifitas spatial analogies terhadap pemahaman angka pada anak usia 5-6 tahun. Hasil analisi penelitian menunjukkan adanya efektifitas tersebut dinyatakan dengan terdapat peningkatan pada nilai rata-rata (mean) kelompok eksperimen, terdapat signifikansi 0,000 pada kelompok eksperimen dan kontrol,hasil tersebut menunjukkan terdapat perbedaan pemahaman angka pada anak usia 5-6 tahun yang mendapatkan treatment berupa spatial analogies dengan permainan papan linear angka, selain itu sumbangan efektitas spatial analogies terhadap pemahaman angka sebesar $86 \%$. Dapat disimpulkan bahwa berdasarkan hasil analisis yang telah dilakukan peneliti menunjukkan terdapat efektifitas spatial analogies terhadap pemahaman angka pada anak usia 5-6 tahun.

\section{DAFTAR PUSTAKA}

[1] Navarrete, A., Gómez, M \& Dartnell, P. (2018). Promoting preschoolers' numerical knowledge through spatial analogies: numbers' spatial alignment influences its learning. Contemporary Educational Psychology, 54, 112- 124.

[2] Peraturan Menteri Pendidikan dan Kebudayaan Republik Indonesia Nomor 137. 2014. Tentang standar nasional pendidikan anak usia dini. Jakarta: Departemen Pendidikan dan Kebudayaan Republik Indonesia.
[3] Peraturan Menteri Pendidikan dan Kebudayaan Republik Indonesia Nomor 146 Tahun 2014. Tentang Kurikulum 2013 Pendidikan Anak Usia Dini. Jakarta: Departemen Pendidikan dan Kebudayaan Republik Indonesia.

[4] Siegler, S \& Ramani, B. (2008). Playing linear numerical board games promotes low-income children's numerical development. Developmental Science. Journal of Educational Psychology,11(5), 655-661.

[5] Kamsiyati, Siti. (2012). Pembelajaran matematika untuk guru sd dan calon guru SD. Surakarta: UNS Press.

[6] Erica, L., Bethany, R. (2018). The home math environment: More than numeracy. Early Childhood Research Quarterly.

[7] Siegler, S. \& Ramani, B. (2009). Playing linear number board games-but not circular ones-improves low-income preschoolers'. Journal of Educational Psychology, 101 (3), 545-560. 